\title{
Further Observations on the Properties of Megacin, a Bacteriocin Formed by Bacillus megaterium
}

\author{
By I. B. HOLLAND* \\ Department of Microbiology, The University, Sheffield 10
}

(Received 6 February 1962)

\begin{abstract}
SUMMARY
A sensitive method for the assay of $m \mu g$. amounts of megacin is described. Sensitive organisms adsorb megacin and the saturation concentration is similar to bactericidal concentrations. The death of megacintreated organisms is, however, not coincident with adsorption but can be delayed or prevented by incubation at low temperature. Post-adsorption death is in fact proportional to the incubation temperature. Bactericidal amounts of megacin transform protoplasts of sensitive organisms to empty spherical ghosts and also appear to disrupt the permeability barrier of whole organisms. Megacin does not, however, degrade isolated or intact cytoplasmic membranes.
\end{abstract}

\section{INTRODUCTION}

Ivánovics and his co-workers (Ivánovics \& Alföldi, 1954, 1955; Ivánovics \& Nagy, 1958) discovered that large numbers of strains of Bacillus megaterium isolated from natural sources produced specific antibacterial agents, to which they gave the name megacins. Megacins are regarded as members of the group of highly specific bactericidal substances first reported by Gratia (1925, 1932) and now known as bacteriocins. The formation of bacteriocins appears to be a lethal process (Ozeki, Stocker \& de Margerie, 1959) and in particular in the case of megacin is reminiscent of the production and liberation of induced lysogenic phage (Ivánovics \& Alföldi, 1955, 1957; Ivánovics, Alföldi \& Nagy, 1959a). Nevertheless the bacteriocins appear to be proteins free from nucleic acids (Fredericq, 1957). The megacin produced by $B$. megaterium strain 216 is the only bacteriocin to have been purified (Holland, 1961); it is an acidic (apparently simple) protein of molecular weight 51,000. The present paper is concerned with the antigenic properties of megacin 216 and its mode of action. The development of a sensitive assay procedure for the detection of $\mathrm{m} \mu \mathrm{g}$. amounts of megacin has enabled the potent antibacterial activity of purified megacin to be examined quantitatively.

\section{METHODS}

Bacillus megaterium strain 216 (a megacin producer) and strain $207 \mathrm{M}$ (used for megacin assay) were described previously (Holland, 1961). Escherichia coli $\mathrm{K} 112$ was obtained from Dr F. Jacob (Pasteur Institute, Paris). Peptone broth was used to grow strain $207 \mathrm{M}$, it contained (g.): $1, \mathrm{NaCl}$; 1 , Oxoid peptone; $0 \cdot 1$, Lab. Lemco; water to $100 \mathrm{ml}$; final $\mathrm{pH} 7 \cdot 2$. Glucose $(0 \cdot 2 \% \mathrm{w} / \mathrm{v}$, final concentration) was added

* Present address : Microbiology Unit, Department of Biochemistry, University of Oxford. 
aseptically when required. Nutrient broth contained (g.): 1, oxoid tryptone; 0.5, Difco yeast extract; 0.5, Lab. Lemco; in $100 \mathrm{ml}$. of distilled water; final pH 7.2. The preparation of other media, purified megacin and the estimation of protein all followed the methods already described (Holland, 1961).

Total organism counts were made with a Thoma haemocytometer cell; bacterial suspensions diluted to $E \mathbf{0 \cdot 3 - 0 \cdot 4}$; each count completed in triplicate.

Viable counts. The suspensions of organisms were diluted at room temperature with nutrient broth or peptone broth, to $2 \times 10^{3}-4 \times 10^{3}$ organisms $/ \mathrm{ml}$; $0.1 \mathrm{ml}$. volumes were spread on the surface of nutrient agar plates, previously warmed to $37^{\circ}$. The plates were incubated at $37^{\circ}$ for 14-16 hr. and the colonies then counted. The diluted suspensions were plated in triplicate; where possible duplicate dilution series were also prepared and plated.

Plating efficiency. This is expressed as percentage viable count compared with total cell count. Well aerated cultures of Bacillus megaterium strain $207 \mathrm{M}$ in the stationary or late logarithmic growth phase consist mostly of single cell organisms with a small proportion of two-celled organisms. When the latter were considered as single viable units, good agreement was found between total and viable counts.

Protoplasts. Protoplasts of Bacillus megaterium strain $207 \mathrm{M}$ were prepared in phosphate buffer or nutrient broth as described by Weibull (1953) and McQuillen (1956) using $14 \mathrm{hr}$. nutrient broth cultures grown at $37^{\circ}$ and with lysozyme (Armour Laboratories) at $100 \mu \mathrm{g} . / \mathrm{mg}$. dry wt. organism; the stabilizing agent was $0.2 \mathrm{~m}$ sucrose. The behaviour and morphology of the resulting protoplasts resembled those described by Weibull (1953).

Cytoplasmic membrane fractions. These were obtained from protoplast preparations by the method of Weibull \& Bergström (1958) in the additional presence of $10^{-2} \mathrm{M}$ $\mathrm{NaCl}+5 \times 10^{-3} \mathrm{M}-\mathrm{MgCl}_{2}$. The product, a pink pellet constituting about $17 \%(\mathrm{w} / \mathrm{v})$ of the initial dry weight organism, was suspended in phosphate buffer or nutrient broth and was used immediately.

Cell wall prepararions of Bacillus megaterium strain $207 M$. Cell walls were prepared according to Salton \& Horne (1951) and suspended in a small volume of phosphate buffer or nutrient broth and kept at $4^{\circ}$; total recovery was $10 \%(\mathrm{w} / \mathrm{v})$ of the initial cell dry weight.

Megacin antiserum. Freshly diluted solutions of purified megacin in sterile phosphate buffer were injected intravenously twice weekly into rabbits (96 $\mu \mathrm{g}$. protein/ml./injection). Where required the megacin was mixed $(1+1)$ with an adjuvant which consisted of 9 vol. Bayol F (supplied by Esso, Queen Anne's Gate, London, S.W. 1) and 1 vol. Arlasel A (Honeywell \& Atlas, Chadwell Heath, Essex). Samples of blood were taken 7 days after the completion of each series of injections; the blood was allowed to clot and the serum obtained by centrifugation.

Phosphate buffer, $\mathrm{Na}_{2} \mathrm{HPO}_{4}+\mathrm{NaH}_{2} \mathrm{PO}_{4}$, was prepared according to Heppel (1957) and unless otherwise stated was $0.02 \mathrm{M}$ and at $\mathrm{pH} 7 \cdot 1$.

The turbidity $(E)$ of growing cultures or suspensions of bacteria was measured at $610 \mathrm{~m} \mu$ with an SP 600 Unicam spectrophotometer with $1 \mathrm{~cm}$. glass cells, or with an Eel nephelometer using a barium sulphate standard.

Specific activity of all preparations was defined as units megacin activity/mg. protein, megacin activity being determined by the plate assay (Holland, 1961). Samples of the purified megacin were kept in phosphate buffer at $-15^{\circ}$ and since 
the activity of the preparations declined slowly over several months the specific activity of megacin was always determined immediately before use when examining the mode of action.

Bactericidal action of purified megacin under standard conditions. In addition to the assay system described previously a method was devised to detect much smaller amounts of megacin. Strain $207 \mathbf{M}$ of Bacillus megaterium was grown in peptone broth $+0.2 \%(\mathrm{w} / \mathrm{v})$ glucose, with shaking in a water bath at $30^{\circ}$. The organisms were harvested at the end of the first growth phase (see Fig. 2), washed and resuspended in peptone broth + glucose to a concentration equiv. $340 \mu \mathrm{g}$. dry wt. organisms $/ \mathrm{ml}$. ( $E$ 0.72; about $1.7 \times 10^{8}$ organisms $/ \mathrm{ml}$.). After equilibration at $37^{\circ}$ for $10 \mathrm{~min}$. the suspension was mixed with an equal volume of megacin solution in phosphate buffer. In most experiments $10 \cdot 1 \mathrm{~m} \mu \mathrm{g}$ (final concentration) of megacinprotein $/ \mathrm{ml}$. was used. After $20 \mathrm{~min}$. the suspension was rapidly diluted and the viable count determined (at $37^{\circ}$ ) and compared with that of the untreated control suspension. With megacin preparations of specific activity $5.63 \times 10^{5}$ the death of $60-90 \%$ of the treated organisms was usually obtained in these conditions.

\section{RESULTS}

\section{Antigenic properties of megacin}

Megacin is a potent antigen which elicits the formation of both precipitating and neutralizing antibodies in rabbit serum. In the presence of adjuvant the amount of neutralizing antibody increases to a titre of 200 after 7 weeks ( 12 injections) and, after further injections, in the 9 th week to 600 (adjuvant antiserum, see Table 1).

\section{Table 1. Neutralization activity of megacin antisera}

Rabbits injected twice weekly for 9 weeks, each dose $96 \mu \mathrm{g}$. megacin protein/injection with an adjuvant, Bayol $\mathbf{F}+$ Arlasel $\mathbf{A}$. Twofold serial dilutions of serum in saline (final volume $0.5 \mathrm{ml}$.) mixed with $0.22 \mu \mathrm{g}$. megacin protein in $0.5 \mathrm{ml}$. phosphate buffer, incubated at $37^{\circ}$ for $2 \mathrm{hr}$. kept overnight at $4^{\circ}$. Residual megacin activity measured by standard plate procedure. Control solutions containing megacin but no serum were included. The neutralization titres given are the means of duplicate assays.

$\begin{array}{cccc}\begin{array}{c}\text { Rabbit } \\ \text { no. }\end{array} & & \begin{array}{c}\text { Period } \\ \text { (weeks) }\end{array} & \begin{array}{c}\text { Neutraliza- } \\ \text { tion titre }\end{array} \\ 1 & \text { Adjuvant serum } & 7 & 200 \\ & & 9 & 600 \\ 2 & \text { Non-adjuvant serum } & 14 & 100 \\ 3 & & 9 & 64 \\ & \text { Non-immune serum } & 9 & 32 \\ & & \end{array}$

The injections then ceased and the antibody titre decreases to 100 after 5 more weeks. Antiserum prepared in the absence of adjuvant (non-adjuvant antiserum) reached a maximum titre only of 64 and the sera from a non-immune animal did not inhibit megacin activity at a $1 / 2$ dilution. The precipitin titre of different sera in presence of megacin in saline was also determined (Table 2). With antiserum (adjuvant) precipitates were formed at all concentrations of megacin tested; the maximum precipitate was obtained at a megacin concentration of $22 \mu \mathrm{g}$. protein $/ \mathrm{ml}$. The supernatant fluids from all these suspensions were not active; the precipitates 
when resuspended were also not active. Thus the antiserum precipitated and neutralized the megacin antigen; non-immune serum and non-adjuvant antiserum did not precipitate or neutralize megacin under these conditions.

\section{Table 2. Precipitation titre of megacin antiserum}

Rabbit serum obtained as in Table 1 (7 weeks) diluted $1+1$ with $0.5 \mathrm{ml}$. aliquots incubated in $4 \mathrm{ml}$. test tubes with $0.5 \mathrm{ml}$. megacin solution (prepared in saline), $2 \mathrm{hr}$. at $37^{\circ}$ and kept at $4^{\circ}$ for $72 \mathrm{hr}$. Precipitation scored by inspection, supernatants assayed for megacin after centrifuging.

\begin{tabular}{|c|c|c|c|c|c|c|}
\hline \multirow{2}{*}{$\begin{array}{c}\text { Megacin } \\
\text { protein } \\
\text { final } \\
\text { concn. } \\
(\mu \mathrm{g} . / \mathrm{ml} .)\end{array}$} & \multicolumn{3}{|c|}{$\begin{array}{c}\text { Supernatant activity } \\
\left(10^{-8} \text { units megacin } / \mathrm{ml} .\right)\end{array}$} & \multicolumn{3}{|c|}{ Degree of precipitation } \\
\hline & $\begin{array}{l}\text { Adjuvant } \\
\text { serum }\end{array}$ & $\begin{array}{l}\text { Non- } \\
\text { adjuvant } \\
\text { serum }\end{array}$ & $\begin{array}{l}\text { Non- } \\
\text { immune } \\
\text { serum }\end{array}$ & $\begin{array}{l}\text { Adjuvant } \\
\text { serum }\end{array}$ & $\begin{array}{l}\text { Non- } \\
\text { adjuvant } \\
\text { serum }\end{array}$ & $\begin{array}{l}\text { Non- } \\
\text { immune } \\
\text { serum }\end{array}$ \\
\hline 88 & $0 \cdot 50$ & $10 \cdot 0$ & $10 \cdot 0$ & ++ & - & - \\
\hline 44 & $0 \cdot 05$ & $5 \cdot 0$ & $5 \cdot 0$ & +++ & - & - \\
\hline 22 & $0 \cdot 05$ & $1 \cdot 0$ & $1 \cdot 0$ & $+++t$ & - & - \\
\hline 11 & 0.05 & $1 \cdot 0$ & - & $++t$ & - & - \\
\hline $5 \cdot 5$ & 0.05 & 0.01 & $0 \cdot 10$ & ++ & - & - \\
\hline $2 \cdot 8$ & 0.05 & $0 \cdot 01$ & $0 \cdot 10$ & + & - & - \\
\hline $\mathbf{0}$ & - & - & - & - & 一 & - \\
\hline
\end{tabular}

Antibacterial activity of megacin

Bacillus megaterium strain $207 \mathrm{M}$ was grown in nutrient broth for $14 \mathrm{hr}$. and the early stationary phase organisms were harvested, washed and resuspended in broth. Samples $\left(1 \mathrm{ml}\right.$.) were equilibrated at $37^{\circ}$ and mixed with $1 \mathrm{ml}$. samples of sterile phosphate buffer containing different amounts of megacin. After $20 \mathrm{~min}$. each sample was diluted 2500 times in broth to prevent further adsorption of megacin; after further dilution the number of surviving colony formers was determined. The number of organisms killed was proportional to the megacin concentration (Fig. 1) except at the highest values where increasing megacin concentration caused only a small increase in the number of organisms killed. Although there was some variation from experiment to experiment a concentration of $1.5-6.0 \mathrm{~m} \mu \mathrm{g}$. megacin preparation $/ \mathrm{ml}$. was required to kill $\mathbf{5 0} \%$ of the organisms in these conditions. In the experiments where megacin was most active, calculation showed about 100 molecules megacin/organism (Fig. 1).

\section{The mechanism of action of megacin}

\section{Conditions for assay of megacin}

To carry out a quantitative investigation of the bactericidal action of megacin, a method for the detection of minute amounts of the antibacterial agent was required; several technical difficulties had to be overcome before a reproducible system was obtained. Although the experiments described above (Fig. 1) were completed successfully, other similar experiments failed because of the premature death (often associated with lysis) of most of the untreated as well as the treated cells. The main requirements were three-fold to obtain: (1) organisms of uniform size consisting as far as possible of single cells; (2) physiologically active suspensions which when subjected to a variety of environmental conditions would still plate 
with a high efficiency, and (3) organisms which gave a reproducible response to megacin under standard conditions. To meet the first of these requirements organisms were always harvested from the stationary phase since at this stage the culture consisted almost entirely of single cells. (Moreover these cells, unlike those from the exponential phase, were not so prone to autolysis.) However, the plating efficiency of suspensions of stationary phase organisms was often only 5-10\%, even when there was no visible lysis. In fact it was found, on measuring the growth of strain $207 \mathrm{M}$, that shortly after reaching the stationary phase the viable count

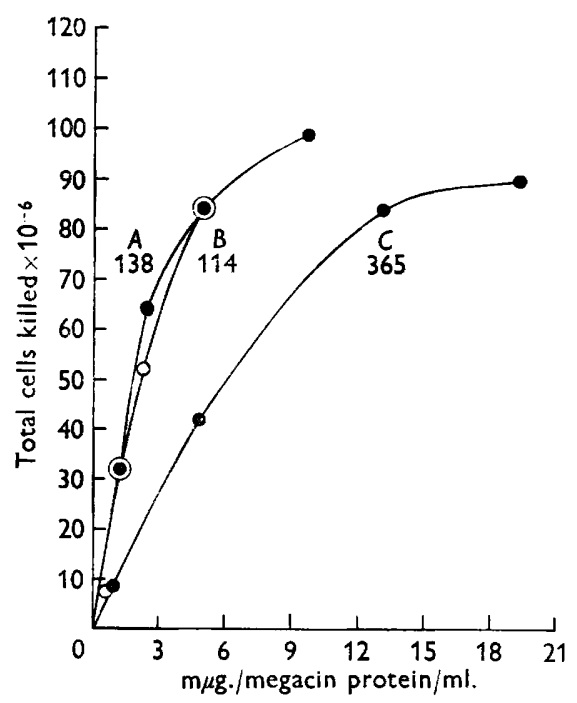

Fig. 1

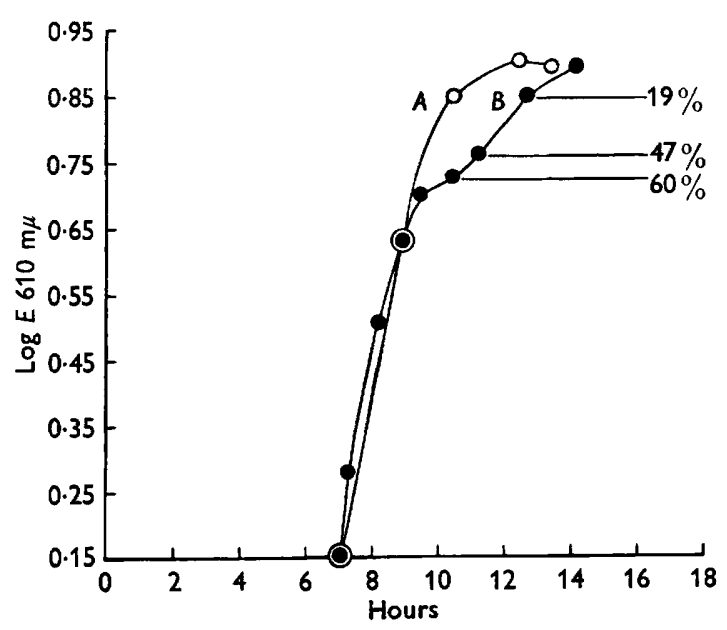

Fig. 2

Fig. 1. Effect of concentration of megacin on viable count of Bacillus megaterium strain $207 \mathrm{M}$ after $20 \mathrm{~min}$. exposure at $37^{\circ}$. Total kill calculated from the viable count of untreated suspensions. $A$, Total count $1.5 \times 10^{8}$ organisms $/ \mathrm{ml}$. (plating efficiency, $57 \%$ ), specific activity megacin $=1.60 \times 10^{6}$ units $/ \mathrm{mg}$. protein; $B$, total count $2.3 \times 10^{8}$ organisms $/ \mathrm{ml}$. (plating efficiency, $56 \%$ ), specific activity $=1.60 \times 10^{6}$ units $/ \mathrm{mg}$. protein; $C$, total count $2 \times 10^{8}$ organisms $/ \mathrm{ml}$., (plating efficiency, $65 \%$ ) specific activity megacin = $\mathbf{5 . 6 3} \times 10^{5}$ units $/ \mathrm{mg}$. protein. Figures by the curve are LD50 values in molecules of megacin/organism.

Fig. 2. Growth of Bacillus megaterium strain $207 \mathrm{M}$ in peptone broth + glucose at $30^{\circ}$, subcultured directly from nutrient broth agar slopes (curve $A$ ), and after several subcultures in peptone broth + glucose (curve $B$ ). Effect of treating organisms of increasing 'age' with megacin $\left(10.1 \mathrm{~m} \mu \mathrm{g}\right.$. $/ \mathrm{ml}$.) at $37^{\circ}$ for $20 \mathrm{~min}$. is shown as percentage kill, indicated by the curve. This was calculated from the viable count of the control untreated suspensions. Specific activity of megacin $=5 \cdot 63 \times 10^{5}$ units $/ \mathrm{mg}$. protein.

usually decreased abruptly. In some cases the turbidity of the culture decreased, indicating that autolysis also occurred. During further studies of the growth of strain $207 \mathrm{M}$ in a variety of conditions it was found that when this strain was grown at $30^{\circ}$ in peptone broth + glucose $(0.2 \%)$, the viable count remained high in the stationary phase. It was subsequently found that the kind of growth curve obtained in this medium depended upon the source of the inoculum. When maintained on nutrient broth agar slopes, immediate subculture in liquid peptone broth + glucose gave the growth pattern shown in Fig. 2 (curve $A$ ). After several sub- 
cultures in peptone broth + glucose however, the growth pattern was as shown in curve $B$. The cultures which showed the 2-step or diauxic growth curve could invariably be harvested between 10-14 hr. to provide washed suspensions whose viable count remained at a high value for several hours. (Plating efficiency, 60$80 \%$.) In contrast, suspensions obtained from single-step growth cultures were occasionally unstable; moreover the discontinuity in the growth curve of the 2-step growth cultures provided an indicator for harvesting under standard and reproducible conditions. Bacillus megaterium strain $207 \mathrm{M}$ was therefore subsequently maintained on peptone broth + glucose agar slopes from which the first subculture showed a diauxie-like growth.

\section{Effect of age of organisms on the response to megacin action}

The instability of organisms harvested before $10 \mathrm{hr}$. (in peptone broth + glucose cultures) prohibited their use for experimental purposes; but the effect of megacin on suspensions of organisms after this was examined. The sensitivity of the bacteria decreased markedly (after $10 \mathrm{hr}$.) (Fig. 2, curve B). Examination of wet mounts of organisms, in the presence of Indian ink (Duguid, 1951) showed that this decrease in sensitivity was concurrent with the progressive development of an extensive slime layer (Pl. 1). It is reasonable to suppose that the slime layer prevented or retarded the penetration of megacin to those structures where it exerted its lethal activity. There is, however, no evidence to indicate that this is a major or a specific mechanism of resistance to megacin.

\section{Adsorption of megacin by Bacillus megaterium strain $207 M$}

In the subsequent experiments organisms were harvested after $10 \mathrm{hr}$. growth in peptone broth + glucose and treated with $10 \cdot 1 \mathrm{~m} \mu \mathrm{g}$. megacin-protein $/ \mathrm{ml}$. (see Methods). This procedure usually resulted in the death of $60-90 \%$ of the bacteria and combined the use of maximum yield of viable organisms harvested under relatively standard conditions with a maximum sensitivity of these organisms to megacin. Adsorption of megacin by sensitive bacteria was now examined. Suspensions of Bacillus megaterium strain 207 M, strain 216 and Escherichia coli $\mathrm{K} 112$ were prepared and exposed to megacin at $37^{\circ}$ in polythene centrifuge tubes (previously sterilized by ultraviolet irradiation); after $20 \mathrm{~min}$. the organisms were quickly centrifuged down and discarded. Control tubes containing megacin but no bacteria were taken through the same procedure. Megacin remaining in the supernatant fluid was estimated by mixing with equal volumes of fresh suspensions of strain $207 \mathrm{M}$ and determining the number of surviving organisms after exposure to the antibiotic for $20 \mathrm{~min}$. The results of three experiments are summarized in Fig. 3. In each case megacin appeared to be completely adsorbed by the $207 \mathrm{M}$ bacteria; the adsorption by the other strains was variable. In all cases the degree of adsorption by the megacin-sensitive strain was higher than by the other two strains.

\section{Saturation level of adsorption by Bacillus megaterium strain $207 \mathrm{M}$}

To verify that megacin adsorption by strain $207 \mathrm{M}$ was specific, the saturation concentration for megacin uptake was determined and compared with those concentrations known to be bactericidal. Suspensions of sensitive bacteria were mixed 


\section{Properties of megacin}

with different concentrations of megacin; after $20 \mathrm{~min}$. at $37^{\circ}$ the suspensions were centrifuged and the bacteria discarded. Two controls containing no bacteria but $\mathbf{2 2} \cdot 1$ and $10.1 \mathrm{~m} \mu \mathrm{g}$. megacin $/ \mathrm{ml}$. respectively, were treated similarly. The supernatant fractions were used to test fresh suspensions of strain $207 \mathrm{M}$, the viable count of which was determined after $20 \mathrm{~min}$. at $37^{\circ}$. The results are shown in Fig. 4. Bacteria mixed with $44.4 \mathrm{~m} \mu \mathrm{g}$. megacin protein $/ \mathrm{ml}$. did not appear to take up all the protein since some megacin activity was detected in the supernatant fluid. At greater concentrations progressively larger amounts of megacin were unadsorbed. A concentration of rather less than $44 \mathrm{~m} \mu \mathrm{g}$. protein $/ \mathrm{ml}$. was therefore sufficient to saturate all the adsorption sites. Incubation with the megacin controls (final concentration, 11.1 and $5.0 \mathrm{~m} \mu \mathrm{g}$. megacin protein $/ \mathrm{ml}$.) caused the death of $31 \%$

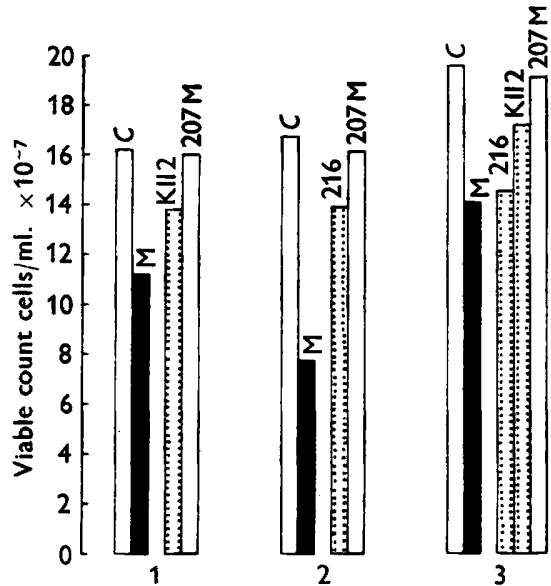

Fig. 3

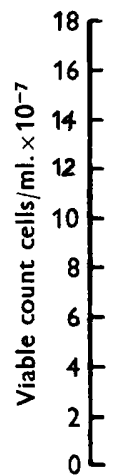

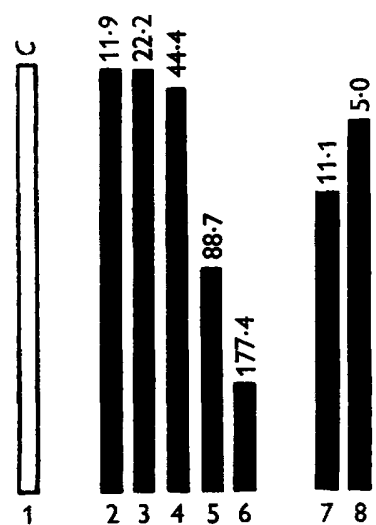

Fig. 4

Fig. 3. Adsorption of megacin by bacteria. Histograms show viable count of Bacillus megaterium strain $207 \mathrm{M}$, after each treatment. Controls ( $C$, open blocks) no megacin; solid blocks, $20 \mathrm{~min}$. with $5.0 \mathrm{~m} \mu \mathrm{g}$. megacin $/ \mathrm{ml}$.; remaining blocks show survival of Bacillus megaterium strain $207 \mathrm{M}$ after exposure to the supernatants obtained after preliminary adsorption of megacin, $(10.1 \mathrm{~m} \mu \mathrm{g} . / \mathrm{ml}$.) by suspensions of Escherichia coli (K 112), B. megaterium 216 (216) and B. megaterium $207 \mathrm{M}$ (207 M). Specific activity megacin $=5 \cdot 63$ units/mg. protein.

Fig. 4. Residual megacin activity after adsorption by Bacillus megaterium strain $207 \mathrm{M}$. Suspensions of cells mixed with various concentrations of megacin at $37^{\circ}$, centrifuged after $20 \mathrm{~min}$. Fresh suspensions of $B$. megaterium $207 \mathrm{M}$ added to supernatants and viable organisms counted after $20 \mathrm{~min}$. Open block, no megacin; solid blocks with initial megacin concentration as stated. Blocks 7 and 8 , viable counts following direct exposure to solutions of known megacin content. Specific activity megacin $=5 \cdot 63 \times 10^{5}$ units $/ \mathrm{mg}$. protein.

and $14 \%$ of the viable bacteria (Fig. 4). The concentration of megacin that is necessary to saturate the adsorption sites is therefore within the range of the bactericidal concentration of megacin.

\section{Survival of megacin-treated organisms at low temperature}

Although adsorption was essential to its bactericidal action, at least one more step is required before the effect of megacin becomes irreversible. Suspensions of 
Bacillus megaterium $207 \mathrm{M}$ were incubated with megacin at $37^{\circ}$ for 20 min., diluted and plated on groups of plates. These were incubated at different temperatures and the colonies counted (Fig. 5). The viable count of the untreated suspension was independent of the final incubation temperature but after megacin treatment it was inversely proportional to the incubation temperature. Thus, although initially exposed to megacin in identical conditions, $\mathbf{3 1} \%$ of the organisms survived when incubated at $37^{\circ}$ whereas $80 \%$ survived if incubated at $15^{\circ}$. The $Q_{10}\left(27^{\circ}-37^{\circ}\right)$ for loss of viability under these conditions was close to 2 (Fig. 6) indicating the possible involvement of an enzymic system.

Adsorption of megacin and death of the organism are therefore two distinct processes since organisms can grow at low temperature, despite the adsorption of

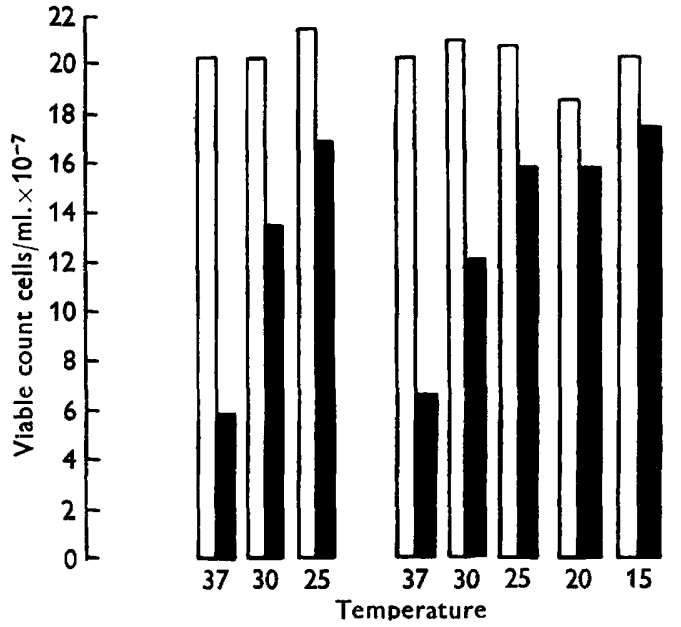

Fig. 5

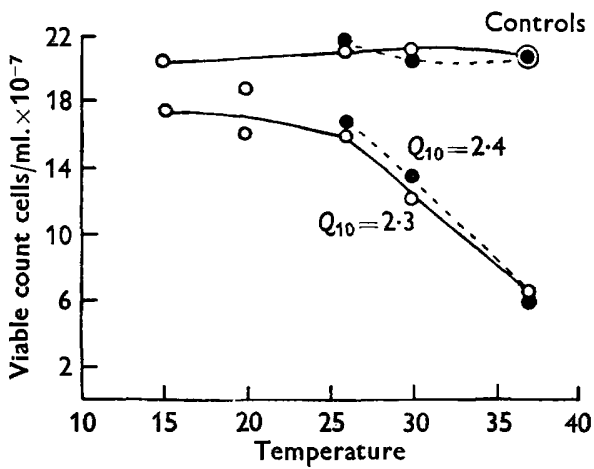

Fig. 6

Fig. 5. Effect of temperature on viability of Bacillus megaterium strain $207 \mathrm{M}$ after adsorption of megacin at $37^{\circ}$. Organism treated with $10.1 \mathrm{~m} \mu \mathrm{g}$. megacin/ml., diluted, plated and incubated at different temperatures. Open blocks, untreated controls; solid blocks, surviving cells at different temperatures.

Fig. 6. Effect of temperature on viability of Bacillus megaterium strain $207 \mathrm{M}$ after adsorption of megacin at $37^{\circ}$. Organisms treated with $10.1 \mathrm{~m} \mu \mathrm{g}$. megacin $/ \mathrm{ml}$., diluted, plated and incubated at different temperatures. Two experiments are shown, specific activity of megacin in each case $=5.63 \times 10^{5}$ units $/ \mathrm{mg}$. protein.

\section{Table 3. Effect of post adsorption temperature on the lethal effect of megacin}

Bacillus megaterium strain $207 \mathrm{M}$ was harvested after $10 \mathrm{hr}$. and resuspended in broth (E. 0.71). The suspensions mixed with megacin $\left(10 \cdot 1 \mathrm{~m} \mu \mathrm{g} . / \mathrm{ml}\right.$. at $37^{\circ}$ for $20 \mathrm{~min}$.) before diluting and plating. Treated and non-treated cells kept at $20^{\circ}$ for $2 \mathrm{hr}$. or $4 \mathrm{hr}$. before incubating at $37^{\circ}$ for $14 \mathrm{hr}$.

\begin{tabular}{|c|c|c|c|c|c|c|c|}
\hline \multirow[b]{2}{*}{ Expt. } & & \multicolumn{2}{|c|}{ Time zero } & \multicolumn{2}{|c|}{2 hr. at $20^{\circ}$} & \multicolumn{2}{|c|}{4 hr. at $20^{\circ}$} \\
\hline & & Controls & Megacin & Controls & Megacin & Controls & Megacin \\
\hline 1 & $\begin{array}{l}\text { Viable count } \\
\text { Cells killed }\end{array}$ & $\begin{array}{c}2 \cdot 01 \times 10^{8} \\
-\end{array}$ & $\begin{array}{c}1.46 \times 10^{8} \\
25 \%\end{array}$ & $2 \cdot 13 \times 10^{8}$ & $\begin{array}{c}1.67 \times 10^{8} \\
22 \%\end{array}$ & $\begin{array}{c}1.93 \times 10^{8} \\
-\end{array}$ & $\begin{array}{c}1 \cdot 76 \times 10^{8} \\
9 \%\end{array}$ \\
\hline 2 & $\begin{array}{l}\text { Viable count } \\
\text { Cells killed }\end{array}$ & $\begin{array}{c}1 \cdot 82 \times 10^{8} \\
-\end{array}$ & $\begin{array}{c}7 \cdot 80 \times 10^{7} \\
57 \%\end{array}$ & $\stackrel{2.32}{-}^{-10^{8}}$ & $\begin{array}{c}1.32 \times 10^{8} \\
43 \%\end{array}$ & - & - \\
\hline
\end{tabular}


a potentially lethal amount of megacin. Recovery, however, is a slow process, treated organisms requiring an appreciable time at $20^{\circ}$ before they can form colonies at $37^{\circ}$, e.g. $4 \mathrm{hr}$. at $20^{\circ}$ enabled $64 \%$ of affected organisms to grow at $37^{\circ}$ (Table 3). After $2 \mathrm{hr}$. at $20^{\circ}$ up to $24 \%$ of affected organisms survived. Treated organisms kept at $4^{\circ}$ did not subsequently recover, confirming the enzymic nature of recovery.

\section{Action of megacin on cell permeability}

Working with partially purified preparations, Ivánovics, Alföldi \& Nagy (1959b) concluded that the megacin produced by Bacillus megaterium strain 216 disrupted the osmotic barrier of sensitive organisms. Purified megacin acts in the same way

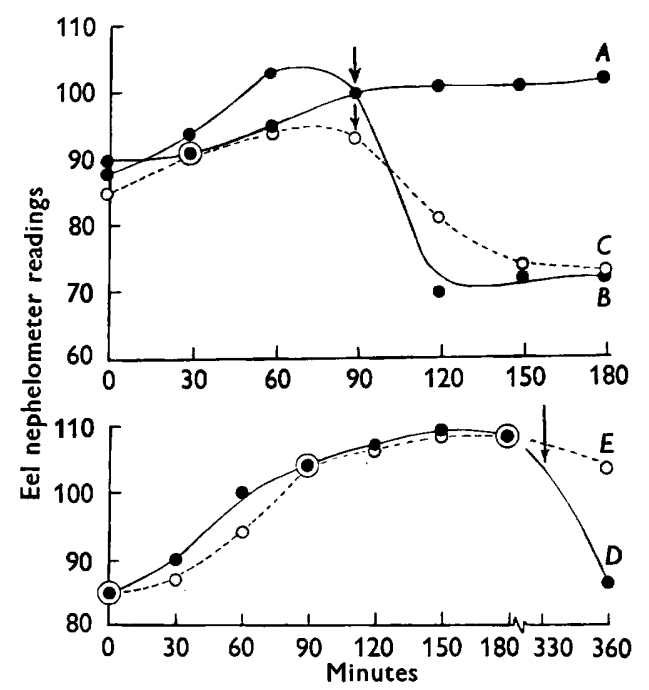

Fig. 7. Action of megacin on protoplasts of Bacillus megaterium strain $207 \mathrm{M}$. Nutrient broth suspensions of protoplasts $\left(9.8 \mathrm{ml}\right.$.) in side arm flasks equilibrated at $37^{\circ}$ for $60 \mathrm{~min}$. Megacin $(0.2 \mathrm{ml}$.) in phosphate buffer added at time zero, changes followed in an Eel nephelometer. $A$, Control no megacin; $B, 962 \mathrm{~m} \mu \mathrm{g}$. megacin $/ \mathrm{ml}$; $C, 481 \mathrm{~m} \mu \mathrm{g}$. megacin $/ \mathrm{ml}$; $D, 48 \mathrm{~m} \mu \mathrm{g}$. megacin $/ \mathrm{ml}$; $E, 4.8 \mathrm{~m} \mu \mathrm{g}$. megacin $/ \mathrm{ml}$. Arrows indicate appearance of protoplast ghosts observed in the phase contrast microscope. Specific activity megacin $=5 \cdot 63 \times 10^{5}$ units $/ \mathrm{mg}$. protein.

converting protoplasts of Bacillus megaterium strain $207 \mathrm{M}$ prepared in broth, to empty spherical ghosts (Fig. 7); this occurred abruptly after a lag period (e.g. $90 \mathrm{~min}$. with the highest megacin concentration). Coincident with the appearance of ghosts, turbidity of the suspension declined. The minimum concentration of megacin producing ghosts was $48 \mathrm{~m} \mu \mathrm{g}$. megacin protein $/ \mathrm{ml}$., and was comparable with that required to kill $60-\mathbf{8 0} \%$ of treated organisms under similar conditions. Whole organisms treated with megacin at $37^{\circ}$ and examined under the phase contrast microscope showed a gradual loss of intracellular material; after 3-6 hr. incubation a few organisms were less refractile and large granules previously almost obscured by the cytoplasm became clearly visible. By $18 \mathrm{hr}$. the suspension was almost clear and the majority of organisms contained only numerous large granules usually 
concentrated at the periphery. The cell envelope, however, appeared to remain intact. In contrast, suspensions of untreated organisms did not show a significant decline in turbidity even after $18 \mathrm{hr}$. and individual organisms appeared normal.

\section{DISCUSSION}

By using a homogeneous purified preparation of megacin at a minimum bactericidal concentration effects due to an excess of the agent have been avoided, and side reactions due to unsuspected trace contaminants minimized. Similarly, by carrying out the experiments with stable cell suspensions (plating efficiency 60 $80 \%$ ) megacin action was measured in relatively quantitative terms. Purified megacin, like the partially purified preparations obtained by Ivánovics et al. $(1959 \mathrm{~b})$ appeared to destroy the permeability barrier of sensitive organisms and protoplasts.

Concentrations producing these changes were similar to those killing such cells, which suggests that the disruption of the permeability barrier and protoplast membrane is a primary cause of the lethal action of megacin. The conclusions of Ivánovics et al. $(1959 b)$ that megacin does not appear to attack the cell wall of sensitive bacteria is supported by the work described above; furthermore, cell wall preparations of $B$. megaterium $207 \mathrm{M}$ in broth, did not decrease in turbidity when incubated at $37^{\circ}$ with the antibiotic ( $74 \mathrm{~m} \mu \mathrm{g}$. megacin $/ \mathrm{mg}$. dry weight cell walls). More interesting, however, was the failure of megacin under the same conditions to alter the turbidity of protoplast membrane fractions of sensitive bacteria, while the ghosts formed by megacin action or protoplasts retained their original size and shape. Hence megacin does not destroy the macrostructure of the protoplast membrane in the intact protoplast or in isolated preparations, and other reasons must be sought for the permeability changes which it induces. If megacin were an esterase like lipase one would expect the protoplast to be degraded, with visible changes in turbidity (cf. Spiegelman, Aronson \& Fitz-James, 1958). If megacin acts like a lysozyme similar changes would be expected with cell wall preparations (cf. Salton, 1957). Ivánovies et al. (1959b) found evidence of neither proteolytic nor detergent activity in their megacin preparations. The very low concentration at which megacin is active $(1-20 \mathrm{~m} \mu \mathrm{g} . / \mathrm{ml}$.) contrasts sharply with the bactericidal concentration of typical surface-active agents, e.g. with polymixin and gramicidin a concentration of $1-25 \mu \mathrm{g} . / \mathrm{ml}$. is required to produce an effect (Newton, 1956; Erlanger \& Goode, 1954). That such low concentrations of megacin could have any direct osmotic effect on sensitive cells is unlikely. Megacin it seems brings about a subtle change within the osmotic membrane and whilst such changes may be caused by a highly specific enzyme, there is as yet no direct evidence for this.

Saturation of the adsorption sites of sensitive organisms requires very low concentrations of megacin which undoubtedly explains the failure of Ivánovics $e t a l$. $(1959 b)$ to demonstrate adsorption, since they tested for uptake by the relatively insensitive plate assay. This adsorption process is not necessarily lethal, since despite having adsorbed a potentially lethal dose of megacin, organisms may recover and remain viable if placed in a suitable environment, e.g. temperatures of the order of $20^{\circ}$. It seems probable that the lesion produced by megacin is concomitant with adsorption but that it is not necessarily fatal unless the organisms 
are immediately exposed to optimum growth conditions. So far experiments with growing organisms have been prohibited by the instability of Bacillus megaterium strain $207 \mathrm{M}$ when subjected to environmental changes. Unfortunately no comparison with the mode of action of other bacteriocins is yet possible since little data, especially with purified compounds, is available.

I wish to record my most grateful thanks to Dr B. A. Fry for his continued interest and helpful discussion of this work and for his invaluable help in the preparation of the manuscript. I have greatly appreciated the interest taken by Professor S. R. Elsden and the help and advice given by all members of this Department. I am also very grateful to Dr J. K. A. Beverly for supplying the megacin anti-serum. Finally I wish to express my thanks to the Medical Research Council for a Training Scholarship.

\section{REFERENCES}

Duguin, J. P. (1951). Demonstration of bacterial capsules and slime. J. Path. Bact. 63, 673.

Erlanger, B. F. \& Goode, L. (1954). Gramicidin S: relationship of cyclic structure to antibiotic activity. Nature, Lond. 174, 840.

Fredericq, P. (1957). Colicins. Annu. Rev. Microbiol. 11, 7.

Gratia, A. (1925). Sur un remarquable example d'antagonisme entre deux souches de Colibacille. C.R. Soc. Biol., Paris, 93, 140.

Gratia, A. (1932). Antagonisme microbien et bacteriophagie. Ann. Inst. Pasteur, 48, 413.

Heppel, L. (1957). In Methods in Enzymology, vol. 3, p. 137. Ed S. P. Colowick \& N. O. Kaplan. New York: Academic Press Inc.

Holland, I. B. (1961). The purification and properties of megacin, a bacteriocin from Bacillus megaterium. Biochem. J. 78, 641.

Ivánovics, G. \& Alföldo, L. (1954). A new antibacterial principle: megacine. Nature, Lond. 174, 465.

Ivánovics, G. \& ALFöldDI, L. (1955). Observations on lysogenesis in Bacillus megaterium and on megacine, the antibacterial principle of this bacillus species. Acta microbiol. Acad. Sci. hung. 2, 275.

Ivánovics, G. \& Alföldi, L. (1957). Bacteriocinogenesis in Bacillus megaterium. J. gen. Microbiol. 16, 522.

Ivánovics, G., Alföldi, L. \& NAGy, E. (1959a). Masked provirus in Bacillus megaterium strains. Acta virol. Acad. Sci., Czech. 3, 23.

Ivánovics, G., Alfördi, L. \& Nagy, E. (1959b). Mode of action of megacin. J. gen. Microbiol. 21, 51.

Ivánovics, G. \& NAGY, E. (1958). Hereditary aberrancy in growth of some Bacillus megaterium strains. J. gen. Microbiol. 19, 407.

McQuillew, K. (1956). In Bacterial Anatomy. Symp. Soc. gen. Microbiol. 6, 127.

Newton, B. A. (1956). The properties and mode of action of the polymyxins. Bact. Rev. $20,14$.

Ozeki, H., Stocker, B. A. D. \& De Margerie, H. (1959). Production of colicine by single bacteria. Nature, Lond. 184, 337.

Salton, M. R. J. (1957). The properties of lysozyme and its action on microorganisms. Bact. Rev. 21, 82.

Salton, M. R. J. \& Horne, R. W. (1951). Studies of the bacterial cell wall. II. Methods of preparation and some properties of the bacterial cell wall. Biochim. biophys. Acta, 7, 177.

Spiegelman, S., Aronson, A. I. \& Fitz-James, P. C. (1958). Isolation and characterization of nuclear bodies from protoplasts of Bacillus megaterium. J. Bact. 75, 102. 
WeIBulL, C. (1953). The isolation of protoplasts from Bacillus megaterium by controlled treatment with lysozyme. J. Bact. 66, 688.

Weibuli, C. \& Bergström, L. (1958). The chemical nature of the cytoplasmic membrane and cell wall of Bacillus megaterium, strain M. Biochim. biophys. Acta, 30, 340.

\section{EXPLANATION OF PLATE 1}

Bacillus megaterium strain $207 \mathrm{~m}$ grown $10 \mathrm{hr}$. in peptone glucose broth showing development of slime layer. Wet mounts of washed cells prepared according to Duguid $(1951) \times 1500$. 
Journal of General Microbiology, Vol. 29, No. 4

Plate 1

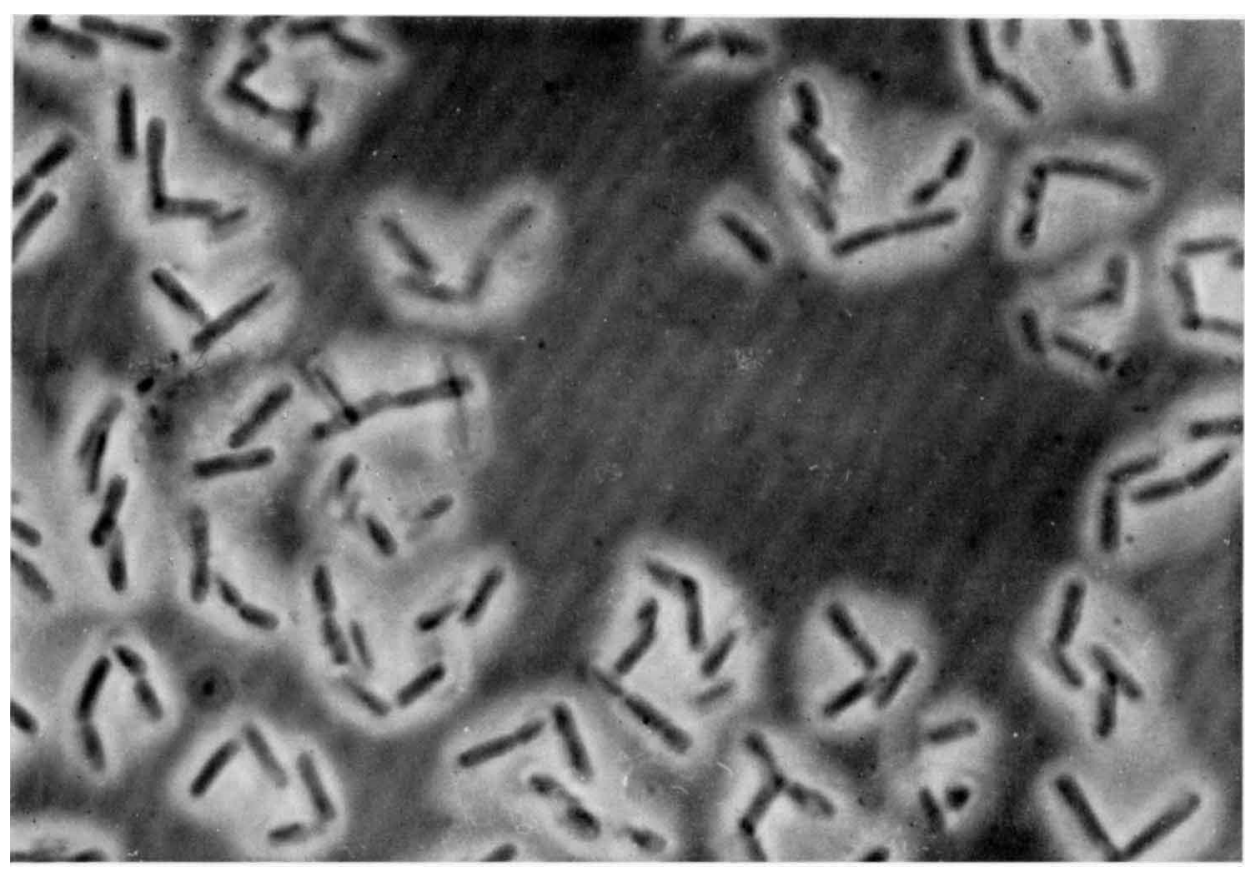

